\title{
AMALAN RESTORATIF DALAM PROGRAM PERLINDUNGAN DAN PEMULIHAN REMAJA HAMIL LUAR NIKAH DI MALAYSIA
}

\author{
Siti Balqis Mohd Azam \\ Calon PhD, Fakulti Undang-Undang, \\ Universiti Malaya. \\ Balqis azam@yahoo.com
}

\section{Abstrak}

Previous studies have proved that therapeutic rehabilitation is an effective intervention for reducing recidivism among delinquent children. The programme involves attempts to bring about behavioural changes by facilitating personal development through improved skills, social relationships, social perceptions, etc. This paper, however, focuses only on one of the main characteristics of the therapeutic rehabilitation which is the restorative programme. Ten pregnant teenagers who are currently enrolled in the rehabilitation and protection programme in the Garden of the Princess, Cheras (Taman Seri Puteri, Cheras) involved voluntarily in the study. To gain the primary data, the researcher performed series of indepth interviews with the ten respondents. Using the interview protocol, the researchers assessing the implementation of the programme based on three main features of restorative practices; the inculcation of responsibility, facilitation of competence skill and the practice of communities reconciliation. The study found that the institution failed to implement the components of the effective restorative programme. The existing programme is generic in its characteristic; not specialised and notpeculiar to the needs of the pregnant teens. As the intervention to the problem, few suggestions are proposed for improving and enhancing the quality of existing programmes of the institution.

Keywords: restorative programme, rehabilitation, pregnant girls 
Pengenalan

Menurut Mohd Al Adib dan Noor Aziah (2009), sistem pengadilan kanak-kanak anti sosial/juvana di Malaysia berasaskan pendekatan pencegahan dan pemulihan. Selama lebih 50 tahun sistem pengadilan juvana berlangsung di negara ini, Mahkamah Bagi Kanak-Kanak telah mengaplikasikan pelbagai teori hukuman seperti pencegahan, retribusi, pengurungan/penahaman (incapacitation) dan pemulihan. Namun begitu, apabila berhadapan dengan pesalah kanak-kanak, Mahkamah Bagi Kanak-Kanak cenderung untuk memilih teori pencegahan dan/atau teori pemulihan. Pendekatan pencegahan dan pemullihan ini dipilih kerana ia paling hampir dengan prinsip atau unsur restoratif yang diyakini mampu menjaga kebajikan dan pembangunan diri kanak-kanak.

Di dalam artikel ini, penulis membincangkan pelaksanaan ciri-ciri pengadilan sistem restoratif dalam program perlindungan dan pemulihan untuk remaja hamil luar nikah di Malaysia. Sebagai perwakilan, perkhidmatan pelindungan dan pemulihan untuk kanak-kanak perempuan di Taman Seri Puteri Cheras (TSP), Kuala Lumpur dipilih. Pada tahun 2013 sehingga 2015 penulis telah menjalankan sebuah kajian kualitatif yang melibatkan 10 orang remaja hamil luar nikah yang berada di dalam perkhidmatan institusi ini. Bagi tujuan penggumpulan data, penulis telah mengunakan teknik temu bual secara mendalam atau in-depth interview.

\section{Pengadilan Restoratif}

'Restoratif' bermakna pembaikpulihan ataupun pemulihan (Smith, 2001). Restoratif adalah satu proses di mana semua pihak yang berkepentingan yang telah terlibat ataupun terjejas daripada perlakuan anti sosial atau delinkuen untuk sama-sama terlibat dalam proses pengadilan. Semua pihak tersebut mempunyai peluang untuk "duduk bersama" membincangkan kesan-kesan negatif jenayah yang telah berlaku ke atas kesejahteraan hidup mereka, serta memutuskan hukuman pemulihan yang paling sesuai dikenakan ke atas individu yang melakukan kesalahan tersebut. Pihak berkepentingan khususnya keluarga, rakan sebaya pesalah, mangsa serta anggota komuniti setempat terlibat bersama-sama dalam proses perbincangan (Braithwaite, 2000). Perbincangan ini dilakukan bertujuan untuk mencari penyelesaian mengenai tindakan yang perlu diambil oleh pesalah untuk memperbaiki keadaan. Perbincangan dianggap berakhir apabila sebuah perjanjian untuk 
memperbaiki kemudaratan ataupun kerosakan yang berlaku dipersetujui oleh semua pihak yang terlibat, khususnya kanak-kanak dan komuniti yang terjejas.

Berbanding dengan sistem keadilan konvensional, terdapat banyak kajian terdahulu yang telah membuktikan keberkesanan program pemulihan yang menerapkan prinsip keadilan restoratif dalam membantu pesalah juvana (Braithwaite, 2002a; Latimer \& Kleinknecht, 2000) serta berjaya mengurangkan pengulangan kesalahan (Latimer, Dowden \& Muise, 2005). Premis asas paradigma pengadilan restoratif adalah jenayah itu satu keganasan dan pencabulan terhadap hubungan manusia; bukannya sekadar percanggahan undang-undang (Zehr, 1990). Justeru itu, tindak balas yang sesuai bagi tingkahlaku jenayah adalah menerusi usaha-usaha memperbaiki kerosakan yang diakibatkan oleh kelakuan jenayah tersebut (Law Commission, 2000). Pengadilan restoratif menyediakan ruang dan peluang untuk pesalah, mangsa dan anggota komuniti untuk sama-sama berbincang tentang kejadian atau perlakuan jenayah yang telah berlaku dan kemudiannya bersama-sama berusaha mencari penyelesaian dan/atau penebusan yang sesuai terhadap jenayah yang telah berlaku.

Bazemore dan Day (1996) menyatakan keberkesanan pemulihan restoratif terletak pada pendekatan Participants in the Balanced and Restorative Approach (BARA) yang mempunyai tiga prinsip pemulihan dan pengadilan yang dipegangnya; iaitu:

(i) Penanaman sikap bertanggungjawab,

(ii) Pembangunan kompetensi; dan,

(iii) Rundingan-permuafakatan awam.

\section{Penanaman sikap bertanggungjawab dalam diri pesalah}

Penanaman sikap bertanggungjawab di dalam konteks pengadilan restoratif merujuk kepada usaha-usaha untuk memastikan pelaku bertanggungjawab ke atas segala kesalahan yang telah dilakukannya. Dalam model sistem pengadilan tradisional, pesalah juga dilihat bertanggungjawab sepenuhnya terhadap kesalahan yang telah dilakukannya. Perbezaannya adalah ia ditentukan sepenuhnya oleh pihak mahkamah dan badan perundangan, serta keputusan yang dijatuhkan adalah rigid. Sebaliknya, di dalam sistem pengadilan restoratif, semua anggota komuniti yang terlibat (pesalah khususnya) terlibat penuh dan secara aktif dalam proses perbincangan mengenai hukuman yang sesuai.

Secara tradisional, apabila sesuatu jenayah berlaku, sistem keadilan jenayah akan menekan kepada tiga persoalan iaitu siapa pelakunya?, apakah 
"barang" yang telah rosak? dan apa yang dilakukan untuk menghukum atau merawat pesalah itu? Sebaliknya, keadilan restoratif menekan kepada tiga soalan yang berbeza iaitu apakah jenis kerosakan yang terhasil daripada jenayah itu?, apa yang diperlukan untuk membetulkan atau memperbaiki kerosakan itu? dan siapa yang bertanggungjawab untuk memperbaikinya? (Zehr, 1990). Ini menunjukkan yang keadilan restoratif lebih menjurus kepada perbincangan mengenai apa yang perlu dilakukan dan sikap bertanggungjawab pesalah untuk memulihkan keadaan.

Program pemulihan teraputik yang bersifat restoratif digunakan untuk membolehkan pesalah menebus balik kesalahan mereka dengan memperbaiki kerosakan atau kemudaratan yang telah dilakukan mereka (Smith, 2001). Anggota komuniti seperti keluarga dan rakan sebaya pesalah, mangsa, dan masyarakat sekitar berhimpun bagi mencari penyelesaian untuk pesalah bertanggungjawab di atas perbuatannya (Bazemore \& Umbreit, 2001). Program ini bertujuan untuk melahirkan sikap bertanggungjawab pesalah; iaitu pesalah dipertanggungjawabkan atas segala tindakan dan perbuatan mereka (Zehr, 1990).

Pengkaji ingin memetik satu contoh program pemulihan restoratif yang melibatkan prinsip penanaman sikap tanggungjawab ini. Program tersebut adalah Program Pengantaraan Mangsa dengan Pesalah (Victim-Offender Mediation atau VOM). Program ini menemukan mangsa dengan pesalah secara bersemuka di bawah seliaan Pengurus Kes yang dilantik. Matlamat utama perjumpaan VOM adalah menyediakan persekitaran yang selamat kepada pihak lain yang terlibat dalam perbincangan. Program VOM dijadikan landasan untuk pesalah, mangsa dan anggota komuniti meluah perasaan kepada pesalah secara langsung; iaitu mengenai impak kesan perbuatan pesalah terhadap mereka. VOM juga menyediakan ruang untuk pesalah menyuarakan pandangan, khususnya bagi membela diri mereka. Program ini mempromosikan rasa atau sikap bertanggungjawab pesalah terhadap perbuatannya dan bersedia menerima apa-apa hasil keputusan perbincangan (Lawson \& Katz, 2004; Van, 2002).

Pengadilan restoratif juga memberi penekanan kepada usaha-usaha memasukkan semula atau mengintegrasi semula pesalah ke dalam kehidupan masyarakat dan memastikan pesalah berusaha untuk berinteraksi dengan jayanya dengan masyarakat. Pendekatan ini melibatkan penyertaan aktif semua anggota komuniti di mana pesalah itu diintegrasikan. Pihak sekolah, rakan sebaya dan komuniti setempat contohnya perlu terlibat dalam program integrasi semula pesalah. Bagi pihak pesalah pula, mereka digalakkan untuk 
"berbakti" atau menyumbang secara produktif tenaga fizikal dan mental mereka dalam pembangunan anggota komuniti setempat. Selain daripada "membalas" semula kesalahan yang telah dilakukan dan menanam semangat bertanggungjawab mengenai kepentingan hidup berkomuniti, penyertaan ini juga berperanan penting dalam merapatkan jurang hubungan antara pesalah dengan anggota komuniti.

\section{Pembangunan kompetensi}

Pendekatan restoratif menyediakan serangkaian program latihan kemahiran sosial untuk kanak-kanak dan remaja mempertingkatkan kemahiran sosial serta kesihatan psikologi mereka. Latihan kemahiran sosial merupakan salah satu komponen penting pemulihan teraputik yang menggabungkan aspek intervensi kognitif dan tingkah laku. Kemahiran sosial merupakan keupayaan individu untuk bertingkah laku dalam mencapai kecekapan sosial mereka (Spence, 2003).

\section{Rundingan-permuafakatan awam (community safety)}

Mengikut prinsip ini, pesalah bertanggungjawab terhadap mangsa (Bazemore \& Umbreit, 2004). Namun, cara penyelesaiannya adalah melalui rundingan permuafakatan yang melibatkan beberapa pihak iaitu pesalah, mangsa dan komuniti yang bersama-sama berbincang mencari hukuman yang sesuai bagi pesalah. Melalui rundingan ini, pesalah diberi peluang "bersuara" dengan menentukan sendiri program pemulihan yang sesuai dengan keperluan dan kemampuannya (Umbreit, 1994).

Prinsip rundingan-permuafakatan yang terkandung dalam sistem pengadilan restoratif mempunyai kaitan rapat dengan usaha untuk menjaga keselamatan awam. Prinsip ini memastikan yang masyarakat tidak lagi "tercedera" atau berada dalam ketakutan disebabkan kelakuan pesalah. Pendekatan ini memberi jaminan keselesaan dan keselamatan kepada mangsa dan komuniti. Prinsip ini mementingkan penglibatan ibu bapa, majikan, guru dan lain-lain untuk mengawasi pesalah. Dengan cara ini juga, pesalah dapat merapatkan hubungan dan/atau mewujudkan kerjasama yang positif di antara mereka. Pihak mahkamah sentiasa memastikan komuniti tidak lagi diganggu oleh pesalah dengan aktiviti-aktiviti delinkuen pada masa akan datang. Beberapa alternatif seperti penyeliaan, sekatan, pemantauan dan penahanan sementara pesalah di institusi pemulihan dan pengawasan yang ketat ke atas mereka mungkin diambil bagi menjamin keselamatan awam (Elis, 2005). 
Pengkaji ingin memetik satu model program pemulihan teraputik restoratif yang ada elemen rundingan-permuafakatan kolektif; iaitu Lembaga Pembaikpulihan Komuniti (Community Reparative Board). Program ini telah dilaksanakan sejak tahun 1995 di Vermont, Amerika Syarikat. Lembaga pembaikpulihan ini menyelesaikan kes juvana bagi kesalahan-kesalahan seperti kecurian, ketagihan alkohol dan dadah, kesalahan seksual dan lain-lain. Program ini, walau bagaimanapun tidak bersesuaian bagi kes-kes juvana berat seperti keganasan terhadap manusia dan harta benda serta melibatkan pembunuhan dan kematian. Lembaga pembaikpulihan ini dianggotai oleh belia-belia setempat, kejiranan dan agensi-agensi tidak formal dan formal. Semua pihak yang berkepentingan (seperti kejiranan, keluarga) berhimpun membincangkan intervensi yang sesuai untuk pesalah dan jumlah pampasan ataupun gantirugi yang sewajarnya kepada mangsa. Semasa mesyuarat pembaikpulihan berlangsung, ahli-ahli lembaga berbincang dengan pesalah mengenai kesalahan dan kesan negatif perbuatannya. Selepas itu, ahli-ahli lembaga akan mencadangkan "hukuman" atau pemulihan atau tindakan spesifik yang sesuai kepada pesalah. Cadangan ini adalah hasil perbincangan dan persetujuan bersama antara pesalah, mangsa dan anggota komuniti. Pesalah diberi jangka masa tertentu untuk menyelesaikan pemulihan dan/atau hukuman tersebut. Setelah perbincangan hukuman selesai dan telah dipersetujui oleh kesemua pihak, lembaga akan menjalankan hukuman yang telah dipersetujui. Mahkamah sentiasa menjalankan pemantauan pematuhan hukuman dan akan menerima laporan dari masa ke semasa daripada pihak lembaga. Apabila tamat mengikuti program yang ditetapkan dan pesalah berjaya menepati kriteria perjanjian, pihak lembaga akan menghantar laporan kepada pihak mahkamah untuk tindakan seterusnya.

Penyertaan pesalah dan anggota komuniti dalam program pemulihan teraputik berkomponen restoratif berlangsung secara sukarela; bukannya penyertaan yang berbentuk paksaan. Menurut Llewllyn dan Howse (1998), elemen ini menyebabkan proses perbincangan kolektif berlangsung secara rela hati dan ini seterusnya membuahkan hasil perbincangan yang memuaskan bagi kesemua pihak yang terlibat. Secara simboliknya, penyertaan sukarela menggambarkan pesalah perlu menerima tanggungjawab diatas kemudaratan yang telah dilakukannya dan menerima secara terbuka perbincangan diatas segala tingkahlaku anti sosialnya. Pihak-pihak yang berkepentingan lain seperti, komuniti, kejiranan dan keluarga pula bersama-sama membantu pesalah dengan menyediakan kaedah yang sesuai untuk memperbaiki kemudaratan. 


\section{Metod}

Pada tahun 2012, penulis telah melakukan kerja lapangan yang intensif bagi mengumpul data dan maklumat terperinci mengenai pelaksanaan program pemulihan teraputik di institusi pemulihan awam. Sebagai perwakilan, pengkaji telah memilih institusi pemulihan dan perlindungan gadis dan kanak-kanak di bawah kelolaan Jabatan Kebajikan Masyarakat Malaysia (JKMM), iaitu Taman Seri Puteri (TSP) sebagai sampel kajian. Dengan menggunakan pendekatan kualitatif sebagai kaedah kajian dan teknik temu bual mendalam (in-depth interview) untuk aktiviti penggumpulan data, pengkaji telah memilih 10 orang pelatih di TSP Cheras, Kuala Lumpur sebagai responden kajian. Pemilihan responden tersebut adalah berdasarkan kriteria-kriteria yang telah ditetapkan oleh kajian. Responden kajian adalah daripada remaja perempuan hamil luar nikah yang berumur dalam lingkungan 14 ke 18 tahun, iaitu masih berada dalam kategori umur kanak-kanak (Akta Kanak-Kanak (Pindaan) 2016). Aktiviti penggumpulan data berjalan selama sembilan bulan di mana pengkaji menemubual responden sehingga tahap tepu (saturation); iaitu apabila responden mengulangi secara kerap maklumat yang sama. Bagi kajian kualitatif, pengumpulan dan analisis data berjalan serentak bagi membina interpretasi data yang koheran. Oleh itu, setiap data yang diterima, pengkaji telah memproses data-data tersebut dengan berpandukan standard pemprosesan yang telah dipilih oleh kajian.

\section{Dapatan Kajian}

Semua responden dalam kajian ini telah dimasukkan ke dalam jagaan institusi perlindungan dan pemulihan awam Taman Seri Puteri sama ada atas arahan Mahkamah Kanak-Kanak Seksyen 40 (3) (a), (Akta 611) dan kanak-kanak yang memerlukan pelindungan segera atas permohonan sendiri (Seksyen 41, Akta 611). Pengkaji menilai amalan pelaksanaan tiga ciri utama program pemulihan yang berasaskan pendekatan sistem pengadilan restoratif; iaitu penanaman sikap bertanggungjawab, pembangunan kompetensi dan inisiatif rundingan permuafakatan awam dalam institusi. Pandangan mereka mengenai aspek ini dilaporkan secara terperinci seperti berikut:

\section{Ketiadaan aktiviti khusus berkaitan penanaman sifat bertanggungjawab} Penanaman sikap bertanggungjawab di dalam konteks pemulihan berasaskan pendekatan restoratif adalah merujuk kepada usaha-usaha untuk memastikan pelaku bertanggungjawab ke atas segala kesalahan yang telah dilakukannya. Ini kerana program restoratif adalah sebuah program yang berusaha untuk 
pesalah menebus balik kesalahan, memperbaiki balik kerosakan yang telah dilakukan dan bersedia menerima apa-apa hasil keputusan yang telah ditetapkan ke atas mereka (Eliis \& Sowers, 2001, Bazemore \& Umbreit, 2001, Law Commission, $2000 \&$ Smith, 2001). Penanaman sifat bertanggungjawab mampu membuatkan kanak-kanak sedar kesan-kesan akibat perbuatan melencong mereka melalui hukuman yang diletakkan atas tanggungjawab mereka dan seterusnya berusaha menyelesaikannya (Barton, 2000).

Pengkaji telah menanyakan responden adakah mereka rasa bersalah dengan kehamilan mereka? Rata-rata responden kajian menyatakan akan perasaan bersalah terhadap perbuatan lampau mereka. Kebanyakan mereka mengatakan kehamilan telah merosakkan masa depan mereka, memalukan keluarga, menghancurkan perasaan ibubapa dan mengganggu pelajaran mereka. Mereka kesal dengan diri sendiri dan keluarga. Mereka mengatakan:

Sha: Haah. Boleh merosakkan masa depan adik. Sebab adik ada anak tanpa suami dan anak ini akan lahir tanpa seorang bapa. Benda ini bagi effect pada masa depan adik.

(Sha, (P4)/24 September 2012/12.55 tengahari)

Khai: Haah. Sangat bersalah dengan kehamilan ini. Yelah sebab pregnant. Lepas tu memalukan famili.

(Khai, (P4)/24 September 2012/12.23 tengahari)

Asma: Memalukan keluarga. Saya ni anak harapan ayah. Rasa macam menghancurkan perasaan dia orang la.

(Asma, (P4)/24 September 2012/12.40 tengahari)

Tehah: Hurm. Ada la. Rasa tu bersalahlah sebab tak sangka boleh sampai pregnant. Ingatkan tak pregnant tapi tak tahu jadi macam ni kan. Dah Tuhan nak tunjuk.... Yang dari segi masa depan. Kira macam mana ek? hurm...Bermasalah lah, nak belajar lagi. Nak bersalin lagi semua ini menganggu je.

(Tehah, (P3)/21 Januari 2013/11.20 pagi) 
Aya: Saya tak rasa bersalah pada kandungan tapi rasa bersalah pada diri sendiri. Itu je. Saya telah hamil. Saya telah hamil luar nikah. Saya nak berubah. Lepas ni saya nak belajar bersungguh-sungguh nak berjaya. Saya tak mahu ulangi kesalahan yang dululah. Yang lepas.

(Aya, (P3)/6 Febuari 2013/2.36 petang)

Nur: Bersalah sebab dah hancurkan hati keluarga, macam saya dah hancurkan masa depan saya, pastu saya rasa, rasa malu la apa yang berlaku dekat diri.

(Nur, (P2)/17 Januari 2013/2.51 petang)

Aen: Bersalah sebab hamil sebelum kahwin. Bersalah pada diri sendiri. Bersalah pada keluarga.

(Aen, (P3)/5 Febuari 2013/11.15 pagi)

Jia: Ya, memang sebab saya belum bersedia untuk jadi ibu. Saya masih muda dan nak sambung belajar lagi. Saya rasa saya nak mula balik selepas ini. Saya ada cita-cita saya. 'Saya minat bidang perubatan.

(Jia, (P2)/7 Febuari 2013/3.59 petang)

Pengkaji mendapati tidak terdapat sebarang usaha oleh pihak institusi untuk membantu klien mereka ini memupuk sikap bertanggungjawab. Ini kerana kesemua responden menyatakan hal ini apabila pengkaji 'probing' responden kajian dengan soalan berikut: 'Adakah program di sini menyentuh mengenai tanggungjawab? tangunggjawab pada diri? dan tanggungjawab ke atas kesalahan yang telah adik lakukan? Berikut adalah antara respons yang diberikan oleh responden kajian ini terhadap soalan tersebut.

Sha: Hurm. Tentang tanggungjawab ni, program ini memang tak ada. Program kat sini cuma ada program mengaji, solat, memasak, menjahit, kemas-kemas dapur, kemas tempat tidur. Itu jelah. Macam program untuk memupuk sikap-sikap diri kita semua tak ada. Dia orang tak ada 
buat la. Biasanya bab-bab tanggungjawab ni, dia orang sentuh dalam ceramah-ceramah, biasanya ceramah jemputan dan sukarelawan luar je. Tiada program tanggungjawab macam ni.

(Sha, (P7)/2 Feburari 2013/12.07 tengah hari)

Khai: Ceramah. Ceramah daripada ustaz Jabatan Agama Islam. Dia berceramahlah tentang seorang wanita perlu bertanggungjawablah ke atas baby, tak boleh buang.

(Khai, (P3)/21 September 2012/11.13 tengahari)

Tehah: Program agama, hurm ada la. Ceramah daripada ustaz-ustaz datang. Ceramah-ceramah daripada ustaz-ustaz bagi kesedaran untuk berubah.Pastu sayang kat baby ni, kat kandungan, ingat dekat mak ayah, dan macam-macam la. Ustaz dari jemputan luar. Ustazah kat sini ada bagi nasihat. Dia suruh berubah bila keluar nanti, jangan buat lagi.Ingat dosa yang dah lepas tu, buang cerita-cerita yang dulu, kira jangan ingat la. Ustazah pun ada cakap ingat, sayang kat baby tu kira ingat la dia tu tak dosa semuanya.

(Tehah, (P3)/21 Januari 2013/11.20 pagi)

Nur: Program agama. Dia cerita tu babitkan, ada selitkan dengan pasal kehamilan. Pastu dia ada tunjuk video pasal agama. Lama tu, rasa la, rasa macam ada kesedaran, rasa macam tanggung...macam betol-betol nak berubah la, nak jaga, macam sayangkan baby ni.

(Nur, (P2)/17 Januari 2013, 2.22 petang)

Aya, Eira dan Aen pula mengatakan sememangnya tiada program yang berusaha memupuk dan/atau menekankan sikap bertanggungjawab ke dalam diri mereka. Cuma, kadang-kadang ustazah di institusi berkenaaan secara spontan ada menyentuh mengenai sikap bertanggungjawab. Mereka mengatakan: 
Aya: Tak ada. Hanya program agama yang sentuh sedikit mengenai sikap bertanggungjawab. Itu pun secara spontan. Sekadar nasihat daripada ustazah.

(Aya, (P3)/6 Febuari 2013/2.20 petang)

Eira: Selama saya duduk dekat sini. Saya belajar tentang membaca Al-Quran, zikir....itu je. Sikap bertanggungjawab tak ada. Selama saya duduk dekat sini, tak ada lagi la ustazah cakap macam tu.

(Eira, (P3)/23 Januari 2013/2.48 petang)

Aen: Kat sini tiada program yang menekan sikap bertangungjawab. Cuma program agamalah, ada sikitsikit menyentuh. Itupun secara umum.

(Aen, (P3)/ 5 Febuari 2013/10.37 pagi)

Selain responden, pengkaji juga turut menemubual pegawai institusi pemulihan TSP mengenai usaha mereka di dalam memupuk sikap bertanggungjawab ke dalam program pemulihan sosial sedia ada. Pengkaji mendapati sikap tanggungjawab yang cuba dipupuk adalah tanggungjawab pada diri sendiri. Ianya termasuk tanggungjawab menjaga diri atau memperbaiki kelemahan diri dan tanggungjawab untuk keberanian serta berdisiplin. Pengkaji turut mendapati ketiadaan program spesik/khas yang bertujuan untuk penanaman sikap bertanggungjawab. Penanaman sikap bertanggungjawab hanya diserap dan/atau disertakan dalam perhimpunan pagi yang diadakan setiap minggu. Pengkaji bertanyakan soalan berikut 'adakah program kat sini pupuk supaya kanak-kanak bersifat bertanggungjawab?' Salah seorang daripada Pegawai Senior TSP dan Pengetua TSP, mewakili kakitangan yang lain mengatakan:

Pegawai TSP: Kenalah. Sebabnya dia datang sini perlulah dia lebih bertanggungjawab sebab sebelum ni dia di rumah, ibubapa yang lebih bertanggungjawab dengan dia kan? Dekat sini kita kena didik dia lah. Kalau sebelum ini dia tak boleh nak sembahyang....Itulah seumpama disiplin yang kita terapkanlah... Jangan takut berhadapan dengan 
orang.Memanglah mula-mula tu macam malumalu, takut tapi bila dah biasa dia macam boleh lah sikit-sikit daripada tak bercakap tu, dah bolehlah. Maknanya yang dah bercakap tu memang dah boleh... Suruh berani lah, bukan semuanya dari bandar, ada juga yang dari kampung.

( Kaunselor, (P1)/10 Febuari 2014/9.50 pagi)

\begin{abstract}
Pengetua: Tiap kali hari Isnin dengan Selasa, Khamis kita ada perhimpunan pagi untuk dia orang berkumpul. Pada masa itu kita bagi tugaslah, sorang membaca nilai-nilai murni, tugas untuk jadi ketua di masa hari itulah.
\end{abstract}

(Pengetua, (P1)/10 Febuari 2014/9.50 pagi)

Pendek kata, analisis daripada verbatim-verbatim di atas mendapati program pemulihan sosial di TSP tidak menekankan kepentingan penanaman sikap bertanggungjawab dalam kalangan remaja perempuan yang di bawah jagaannya. Ini kerana pengkaji tidak dapat melihat perlaksanaan sebarang 'aktiviti khas' yang bertujuan untuk penanaman sikap bertanggungjawab. Penanaman sikap bertanggungjawab ini hanya disentuh sepintas lalu melalui aktiviti keagamaan, perhimpunan pagi dan secara nasihat. Sikap bertanggungjawab yang cuba diterapkan pula lebih dilihat daripada sudut agama Islam seperti tidak melakukan dosa lagi, bertaubat dengan mengadakan solat, berzikir dan mengaji, serta nasihat agar jangan menggugurkan kandungan kerana perbuatan itu berdosa dalam Islam.

\title{
Program pembangunan kompetensi diri bersifat konvensional, tidak menyeluruh dan gagal mencerap keperluan remaja hamil
}

Antara praktis yang menjadi keutamaan perlaksanaan program pembangunan kompentensi diri adalah pengisian kemahiran vokasional, penyediaan pengalaman bekerja, pemenuhan kemahiran-kemahiran sosial seperti kemahiran berkomunikasi dan berinteraksi, program penjanaan pendapatan dan keupayaan kebolehpasaran kerja yang produktif. Pendek kata, pembangunan kompetensi diri merujuk kepada penyediaan peluang kepada remaja dengan membangunkan kemahiran dan sumber-sumber yang diperlukan oleh mereka agar dapat berfungsi secara positif dalam masyarakat (Barton, 2000; Maloney, Romig \& Armstrong, 1998). 
Pengkaji telah bertanyakan soalan ini kepada responden kajian 'adakah terdapat program yang bertujuan untuk membangunkan kompetensi diri atau kebolehan adik?' Berdasarkan respons yang diberikan, pengkaji boleh menyimpulkan yang program pembangunan kompetensi diri ada dilaksanakan di TSP. Remaja perempuan yang mengikuti perkhidmatan ini dilatih dengan kemahiran seperti memasak, menjahit, berkebun dan latihan didapur; iaitu lebih ke arah kepada program Ekonomi Rumah Tangga (ERT). Program pembangunan kompetensi; khususnya program kemahiran sosialnya lebih terfokus kepada pendekatan vokasional yang bersifat gender seperti menjahit, memasak dan berkebun. Pihak institusi juga dilihat begitu memberikan penekanan kepada aktiviti keagamaan berbanding aktiviti pembangunan kompetensi yang lain. Hampir setiap hari program keagamaan disediakan kepada mereka. Segelintir daripada responden telah mengkritik programprogram yang diikuti mereka. Kata mereka:

Aya: Kat sini lebih kepada program agama seperti mengaji, hafal Al-Quran, solat, baca yasin lepas tu belajar masak, menjahit. Pagi-pagi berkebun, itu jelah

$$
\text { (Aya, (P3)/6 Febuari 2013/2.20 petang) }
$$

Eira: Selama ni, yang saya duduk dekat sini, yang saya belajar
tentang membaca Al-Quran, zikir. Itu je.

(Eira, (P3)/23 Januari 2013/2.48 petang)

Aen: Kat sini macam program vokasional, jahit-jahit, masakmasak, berkebun, silat, program agama. Itu jelah.

(Aen, (P3)/ 5 Febuari 2013/10.37 pagi)

Perkembangan pemulihan teraputik yang efektif di negara maju memperlihatkan yang program pembangunan kompentensi diri turut melibatkan peranan komuniti (Stuart, 1996; Melton, 1995). Komuniti menjadi sebahagian rakan kepada sistem pengadilan kanak-kanak dengan bersamasama membangunkan peluang-peluang untuk pesalah muda membuat sumbangan yang produktif kepada komuniti dan belajar tentang sivik hidup dan nilai-nilai kemasyarakatan (U. S Department of Education, 2013). Pesalah muda digalakkan untuk "berbakti" atau menyumbangkan secara produktif 
tenaga fizikal dan mental mereka dalam pembangunan anggota komuniti setempat. Pengkaji ingin melihat adakah komponen pembangunan kompentensi diri sepertimana yang disyorkan oleh modul pengadilan restoratif di Amerika Syarikat itu ada diterapkan di dalam program pemulihan teraputik di TSP. Pengkaji telah menanyakan soalan ini "Adakah program kat sini melibatkan masyarakat setempat?" Di antara mereka mengatakan:

Sha: Masyarakat sekeliling itu memang tiada. Syarikat-syarikat persendirian, macam syarikat besar-besar itu tak pernah lagi. Tapi kat sini ada projek membuat sabun dan buat tudung saji dengan pengusaha luar. Pengusaha tu bekalkan sabun untuk hotel-hotel. Bila terdapat permintaan mereka datanglah mengajar dan upah kami buat kraftangan mereka. Lepas tu kan, setiap minggu ada guru daripada KEMAS datang ajar kami menjahit. Itu jelah yang selalu datang beraktiviti dengan kami, tak banyak pun.

(Sha, (P8)/3 Jun 2013/2.00 petang)

Sha: Tapi kalau kita orang macam umur 17 ke 15 tu nak ambil exam macam PMR ke SPM dia orang akan usahakan lah. Nak ambilkan slip ke apa daripada sekolah. Telefon famili macam mana kita orang nak ambil exam ke tak. Macam baru-baru ni, PMR, ada 3 orang pelajar penghuni kat sini, ambil PMR kat sinikan, JKM sini lah usahakan ambil slip, minta famili hantar ataupun dia orang pergi sendiri ke sekolah kita ambil slip kita orang. Kita orang exam kat sini la, ada pemeriksa datang sini, jaga kita orang.

Hurm. Ada jabatan agama Islam. JAIS. Tu pun semasa saya kat sini, sekali jelah. Dia orang datang buat ceramah pasal sosial kita orang.

Ada wakil dari universiti. Selalunya daripada UKM, Universiti Malaya ke. Ada akak-akak selalu datang bagi kita orang advice la kat kita orang. Baru-baru ni, minggu lepas tak silap saya, ada akak daripada U tu, dia orang bagi kita orang ceramah tentang sosial, macam mana kita boleh jadi macam ni, macam boleh pregnant, 
hubungan kita dengan keluarga dengan rakan-rakan semua.

(Sha, (P6)/24 Oktober 2012/12.30 tgh)

Bai: Ada untuk peperiksaan. Contohnya sekarang SPM... Hurm. JAIS, JKM, polis.

(Bai, (P5)/24 Oktober 2012/12.45 tgh)

Khai: Ada kalau pihak sekolah tu. Dia orang just siapa yang nak ambil exam tu jelah. Bekerjasama adalah. Macam SPM, PMR tu, dia orang tolong. JAIS, dia orang bagi ceramah tentang macam mana kehidupan sosial ni, budak-budak kat luar macam mana, tentang pembuangan bayi sedang meningkat di usia remaja. Ada orang melawat, wakil dari universiti datang melawat.

(Khai, (P6)/24 Oktober 2012/1 petang)

Asma: Hari itu polis ada datang, JKM pun ada datang, JAIS pun ada datang sekali. Datang bagi ceramah.

(Asma, (P6)/31 Oktober 2012/10.50 pagi)

Tehah: Wakil dari universiti la. Dia orang buat program, bagi ceramah.Pastu, dia orang buat la program-program lain. Last hari tu bulan 12.

(Tehah, (P3)/21 Januari 2013/12.13 tengah hari)

Aya: ..program kat sini secara tertutup. Tak ada melibatkan orang sekeliling saya.Tetapi, ada juga pelajar-pelajar universiti datanglah buat program; tapi bukan selalu. Itu tergantung kepada universiti itu...Hurm. Ada pelajar universiti buat program kesedaran. Program Dari Hati ke Hati. Pada bulan 12 tahun lepas. Selama satu hari, bagi ceramah, motivasi, itu jelah.

(Aya, (P3)/6 Febuari 2013/3.40 petang) 
Nur: Pelajar UKM. Program bulan 12. Dari Hati ke Hati (Nama program). Dia interview sorang-sorang, dia suruh luahkan apa masalah.Pastu dia orang ada bagi nasihat semua, bagi support la.

(Nur, (P2)/17 Januari 2013/3.37 petang)

Aen: Tiada.Cuma sukarelawanlah datang sini.Kadang-kadang ajar kraftangan.Itupun jarang-jarang. Ada seorang ustaz secara sukarelawan datang mengajar setiap kali, setiap hari rabu.

:Ada. Pelajar-pelajar UKM. Bulan 12 tahun lepas. Macam kongsi masalah dengan kita, nak kongsi masalah dengan dia, bagi ceramah. Dia orang buat program aktiviti macam-macam la sepanjang saya duduk sini. UKM jelah datang buat program ramai-ramai.

(Aen, (P3)/ 5 Febuari 2013/1.09 petang)

Jia: Ada. Volunteer ada datang. Contohnya guru Bahasa English datang mengajar setiap hari khamis. Mengajar English. Puan Suria Ali Suda. Lepas tu ada pelajar universiti juga. Mereka datang mengajar kat sini, buat program kat sini la.

(Jia, (P2)/ 7 Febuari 2013/05.16 petang)

Pada masa yang sama, bagi mendapat kepastian lagi mengenai penglibatan pihak luar ke dalam program institusi, pengkaji turut bertanyakan soalan mengenai perkara tersebut kepada kakitangan institusi pemulihan TSP. Pegawai Senior dan Pengetua TSP mengatakan:

Pegawai Senior: Itu (projek sabun) daripada Kementerian Pembangunan Wanita projek tu. Membuat sumber bahan-bahan apa semua, pihak sana pihak Kementerian yang salurkan. Cuma pihak kita, budak-budak kita yang buat lepas tu diberi upah. Berlatih, apabila dia orang keluar, dia orang boleh buat ini lah perniagaan sabun 
pun mana-mana pun, lebih kurang macam nilah.

(Pegawai Senior TSP, (P1)/10 Febuari 2014/9.50 pagi)

Pengetua: Macam-macam lah. Pelbagailah. Kita tak boleh nak bagi sebab sebelum ni Yayasan Bank Rakyat pun ada buat motivasi kat sini. CIMB ada. Memang pelbagai lah. Setiap tahun ada je orang-orang luar yang berlainanlah. Di samping tu, penghuni juga ada dijemput untuk menghadiri aktiviti kat luar lah. NGO punya institusi juga lah, macam Dar Saa'dah memang selalu kita ikuti program dia orang lah. Dia jemput kita lah.

(Pengetua TSP, (P1)/10 Febuari 2014/9.50 pagi)

Pegawai Senior: Daripada universiti ada. Macam-macam lah, pelbagai. IM4U pun ada. Belia (Kementerian Belia dan Sukan)

(Pegawai Senior, (P1)/10 Februari 2014/9.50 pagi)

Analisis daripada tema-tema di atas menunjukkan program pembangunan kompetensi diri di institusi TSP seperti menjahit, memasak serta kraftangan adalah bersifat gender dan/atau berskop feminin. Bagi komponen pembangunan kompetensi melibatkan komuniti pula, pengkaji mendapati sememangnya terdapat pelbagai kerjasama yang melibatkan komuniti setempat. Pihak komuniti yang dimaksudkan termasuklah sekolah, Jabatan Agama Islam Selangor (JAIS), universiti tempatan, guru-guru sukarelawan, pengusaha industri tempatan, Majlis Belia dan badan-badan korporat seperti Bank Rakyat serta CIMB Bank. Badan-badan korporat seperti Yayasan Bank Rakyat dan CIMB Bank turut mengadakan aktiviti bersama penghuni dengan menganjurkan kem-kem motivasi kesedaran kepada di institusi pemulihan. Pihak institusi pemulihan menjalinkan hubungan dengan sekolah adalah untuk mempermudahkan urusan mengenai peperiksaan (seperti, SPM, PMR) yang bakal yang dihadapi oleh penghuni kelak. Menjelang tarikh peperiksaan, pihak institusi pemulihan dengan bantuan daripada pihak Jabatan Kebajikan Masyarakat (JKM) menguruskan hal-hal seperti penempatan pengawal peperiksaan di institusi pemulihan, penyediaan bahan/buku ulang kaji dan pelbagai lagi. Pihak institusi pemulihan juga telah menerima 
kunjungan/lawatan daripada Jabatan Agama Islam Selangor (JAIS) dan pelajar universiti yang berhampiran. Kebiasaanya, mereka ini giat mengadakan program kesedaran, motivasi dan memberi nasihat/kaunseling mengenai masa depan dan aktiviti yang bertujuan untuk pembangunan semula penghuni.

Seterusnya, terdapat juga pengusaha-pengusaha industri pembuatan mengadakan usaha sama dengan penghuni di institusi pemulihan. Antaranya melibatkan penghuni ke dalam projek membuat sabun dan tudung saji. Manamana penghuni yang terlibat/menyertai projek berkenaan dapat mempelajari kemahiran tersebut dan mereka turut diberikan upah pada setiap penghasilan. Pihak institusi pemulihan sentiasa menerima kunjungan sukarelawansukarelawan yang datang untuk memberi khidmat. Sehingga kini terdapat seorang guru bahasa Inggeris, ustaz dan guru silat yang datang pada setiap minggu mengadakan aktiviti bersama penghuni institusi pemulihan.

Kerjasama atau pakatan dengan komuniti ke dalam institusi pemulihan telah memberikan kesan positif kepada pembangunan dan perkembangan diri penghuni. Ini kerana pengkaji mendapati remaja perempuan yang ditempatkan di institusi pemulihan ini amat memerlukan sokongan daripada komuniti bagi menunjukkan mereka telah diterima semula oleh masyarakat, diberi peluang memulakan kehidupan baru dan menandakan mereka tidak distigma oleh masyarakat disebabkan oleh kehamilan mereka. Di samping itu juga, proses interaksi antara komuniti dengan remaja perempuan ini juga turut memberi ruang dan peluang kepada mereka mempelajari nilai-nilai kemasyarakatan dan sivik hidup untuk dijadi pegangan/panduan kelak.

\section{Ketiadaan amalan rundingan-permuafakatan anggota komuniti}

Rundingan-permuafakatan anggota komuniti setempat berakar umbi kepada kewajipan pesalah untuk bertanggungjawab atas kesalahan mereka. Ianya adalah suatu rundingan dan/atau perbincangan yang juga dikenali sebagai 'segmen dialog' yang melibatkan pesalah bersama-sama komuniti setempat. Menurut Umbreit (1994) matlamat program ini adalah untuk memberikan hak bersuara kepada pesalah dan/atau komuniti untuk meluahkan perasaan mereka. Ia merupakan satu proses pengantaraan di mana pesalah berpeluang berjumpa dengan komuniti dalam keadaan selamat dan harmoni. Ini juga merupakan satu usaha untuk menjaga keselamatan komuniti agar mereka merasa terjamin dan tidak lagi terganggu disebabkan kelakuan pesalah. Daly (2005) mengatakan program ini juga bermaksud perdamaian (reconciliation) di antara pesalah dengan komuniti dan/atau mangsa sekiranya terdapat. Di dalam medium ini, mangsa, komuniti dan pesalah berpeluang meluahkan 
perasaan mereka dan berbincang mencapai persetujuan mengenai ganti rugi kerosakan yang harus dibayar oleh pesalah kepada mereka (Bazemore \& Umbreit, 2001).

Menurut Daly (2005), program ini sering mengadakan perbincangan secara bersemuka di antara pesalah dengan komuniti serta badan-badan sokongan lain. Topik perbincangan adalah mengenai kesalahan dan kesan negatif perbuatan pesalah ke atas diri mereka dan komuniti. Cadangan hukuman yang bersesuaian untuk pesalah haruslah mendapat persetujuan kedua-dua belah pihak iaitu bagi pihak pesalah mahupun komuniti. Mahkamah, khususnya Mahkamah kanak-kanak sentiasa menjalankan pemantauan pematuhan hukuman dan akan menerima laporan dari masa ke semasa daripada perlaksana program dari masa ke semasa.

Mungkin elemen ini tidak sesuai diterapkan sepenuhnya ke dalam sistem pemulihan TSP, bagi menjaga maruah dan keaiban mereka serta keluarga mereka. Walaubagaimana pun, elemen ini masih boleh diterapkan ke dalam institusi pemulihan TSP dengan melibatkan pihak-pihak berkepentingan membincangkan hal ehwal kebajikan dan pembangunan semula penghuni institusi pemulihan. Contohnya, mengadakan bengkel interaktif yang melibatkan para ibubapa. Bengkel ini diadakan dengan kepelbagaian aktiviti seperti aktiviti bersama keluarga, perbincangan menyelesaikan masalah serta konflik dalam keluarga dan pelbagai lagi. Matlamat utama bengkel adalah untuk mewujudkan kerjasama ibu bapa dalam mendidik dan menjaga anak, menyedarkan mereka tentang undang -undang yang perlu dipatuhi dalam kehidupan seharian dan dapat memupuk kesedaran dalam diri peserta dan ibu bapa terhadap kehidupan seharian dan dapat memupuk kesedaran dalam diri perserta serta ibu bapa terhadap tanggungjawab dalam melahirkan keluarga mithali. Secara tidak langsung, aktiviti ini boleh mengeratkan, membina dan memperbaiki semula hubungan silatulrahim di antara para remaja ini dengan anggota keluarga mereka; khususnya dengan ibubapa mereka.

Malangnya, program rundingan permuafakatan komuniti sedikit pun tidak dilaksanakan di dalam mana-mana program pemulihan di TSP. Sepanjang berada di lapangan, pengkaji langsung tidak dapat melihat sebarang aktiviti pengendalian rundingan atau segmen dialog yang melibatkan pesalah dengan komuniti, khususnya ibubapa. Tiada sebarang akitiviti perbincangan/bengkel melibatkan komuniti khususnya ibubapa serta peluang untuk bersuara untuk pesalah mahupun komuniti berlangsung di institusi. Program pemulihan TSP sama sekali tidak menitikberatkan penglibatan komuniti setempat dalam membantu membaikpulih pesalah. 
Malah, pengkaji mendapati program-program yang sedia ada di TSP lebih bersifat autoritarian. Ini kerana penghuni atau pelatih yang mengikuti program ini tidak diberi peluang langsung untuk mengeluarkan pandangan atau pendapat mereka mengenai sesuatu perkara. Mereka perlu akur pada peraturan dan keputusan yang telah ditetapkan buat mereka. Di antara mereka mengatakan:

Sha: Memang tak ada pun. Kalau ada pun penceramah dan sukarelawan luar. Dia orang tanya kenapa jadi macam ni, lepas ni buat apa? nak mulakan hidup macam mana? insaf atau tidak?. Tak adanya nak tanya, nak jemputjemput ibu bapa, masyarakat datang tolong kami berunding...

(Sha, (P7)/2 Feburari 2013/12.07 tengah hari)

Aya: Tak ada. Kat sini tidak diajar untuk berunding, berbincang apabila ada masalah. Biasanya ada masalah fikir-fikir sendiri la cara nak menyelesaikan. Orang kat sini tak ambil tahu hal-hal orang.

(Aya, (P3)/6 Febuari 2013/2.36 petang)

Aen: Tak ada langsung sikap berunding. Berbincang itu boleh fikir-fikir sendiri, tak adanya nak ajar-ajar kat sini.

( Aen, (P3)/ 5 Februari 2013/10.37 pagi)

Nur: Ada. Dia orang kata kalau ada masalah boleh cerita dengan Kaunselor dekat sini. Tak pun cerita dengan kawan yang kita boleh percaya, yang boleh bantu kita, jangan cerita dekat semua orang.

(Nur, (P2)/17 Januari 2013/2.51 petang)

\section{Perbincangan}

Di dalam bahagian ini, pengkaji membincangkan secara terperinci mengenai cadangan modul-modul berasaskan ciri-ciri sistem pengadilan restoratif yang boleh diimplimentasikan ke dalam program pemulihan sosial di TSP bagi 
membantu memulihkan remaja perempuan/kanak-kanak pesalah seksual di institusi pemulihan tersebut secara berkesan.

Modul pemulihan khusus untuk remaja perempuan yang terlibat dengan salahlaku seks; khususnya hamil luar nikah

Model pemulihan ini menekan keperluan penanaman sikap bertanggungjawab ke dalam diri remaja perempuan hamil luar nikah. Ini kerana perkara yang menjadi keutamaan dalam sistam pengadilan restoratif adalah aspek 'kebertanggungjawaban' iaitu 'we want them to be responsible' dalam usaha mengubah/memulihkan mereka (Challeen, 1986). Hasil kajian ini menunjukkan rata-rata responden kajian bersependapat mengatakan komponen penanaman sikap tanggungjawab adalah penting buat mereka, terutamanya tanggungjawab kepada diri sendiri, tanggungjawab kepada kandungan mereka dan tanggungjawab kepada ibubapa. Ianya juga penting untuk pengelakkan pengulangan kesalahan lampau.

Sistem pengadilan restoratif adalah sistem pengadilan yang bukan bertujuan untuk menghukum. Sebaliknya, sistem pengadilan restoratif bermatlamat untuk menjaga kebajikan pesalah; khususnya pesalah muda,melalui rawatan, pendidikan semula dan pembangunan diri (selfdevelopment). Sistem pengadilan ini melihat keterlibatan individu dalam tingkah laku anti sosial/delikuen adalah disebabkan oleh ketidakmatangan akal fikiran; iaitu kegagalan untuk memahami kesan/akibat setiap perbuatan salah laku/devian serta pengaruh persekitaran sekeliling mereka (Walgrave, 2004). Bertitik-tolak daripada andaian ini, sistem pengadilan restoratif memfokuskan kepada tindakan-tindakan remedi sosial yang memberi peluang kepada pesalah untuk memperbetulkan/memperbaiki semula kesilapan dengan cara bertanggungjawab terhadap setiap kesalahan yang telah dilakukan.

Terdapat dua jenis tanggungjawab yang amat ditekankan dalam program pemulihan berasaskan sistem pengadilan restoratif. Pertama, tanggungjawab untuk memperbaiki atau memperbetulkan semula kerosakan/kemudaratan yang dilakukan (Braithwaite, 2002b). Kedua, tanggungjawab untuk memulihkan semula hubungan dengan mereka yang telah terjejas/terlibat dengan kelakuan/tingkah laku anti sosialnya (Kurki, 2000). Terdapat bukti kukuh di mana permohonan maaf amat mempengaruhi proses restoratif. Antaranya ahli-ahli psikologi telah mendapati individu yang telah memperolehi kemaafan daripada mereka yang terjejas/tempias dengan perbuatannya mempunyai persepsi positif mengenai perwatakan atau kesalahan lampau serta berusaha untuk mengelak dan/atau menahan diri 
daripada mengulangi kesalahan (Exline, Worthington, Hill \& McCullough, 2003).

Hasil kajian Allan, Beesley, Attwood \& Mckillop (2013) mengenai permohonan maaf dalam sistem pengadilan restoratif mendapati rata-rata responden kajian yang terdiri daripada orang awam boleh menerima permohonan maaf yang dibuat oleh pesalah, bersependapat di mana permohonan maaf adalah suatu tindakan yang bagus dan meletakkannya sebagai tanggungjawab pesalah. Penerimaan permohonan maaf pesalah membantu mengukuhkan tingkah laku pro sosial mereka.Ia juga boleh menimbulkan rasa hormat anggota komuniti terhadap pesalah yang seterusnya mempengaruhi rasa simpati dan empati mereka dengan tindakan pesalah. Perkara yang paling penting yang terhasil daripada permohonan maaf pesalah adalah ia menggambarkan inisiatif pendamaian dan pengembalian semula keharmonian pesalah dengan pihak-pihak yang terjejas daripada perbuatan salahnya (Kurki, 2000; Choi \& Severson, 2009).

Selain daripada tanggungjawab memperbaiki kemudaratan dan perhubungan, individu turut bertanggungjawab untuk memajukan diri atau membuat perubahan pada diri mereka. Ini kerana matlamat pemulihan/pembaikpulihan dalam sistem pengadilan restoratif adalah berorientasikan ke arah penyediaan kualiti hidup sosial yang tenang/aman seperti penyerapan prinsip-prinsi moral ke dalam diri individu (Walgrave, 2004). Elemen ini dibina berdasarkan kepada prinsip Teori Mengintegrasi Rasa Malu (Reintegrative Shaming Theory).Teori ini melihat restoratif sebagai proses sosialisasi semula jadi keluarga dalam mendidik anak-anak agar mematuhi undang-undang.

Dzur (2003a) mengatakan tindak balas/respons yang tepat terhadap kemudaratan/kerosakan yang berlaku adalah dengan melibatkan individu ke dalam segmen dialog. Perbincangan dalam segmen dialog turut menyentuh hal mengenai kesan-kesan tingkah laku lampau individu, khususnya kesan terhadap komuniti. Terdapat tiga proses yang komprehensif digunakan dalam segmen dialog ini. Proses pertama adalah dengan membuatkan individu mengakui/menyedari kesalahan yang telah dilakukan. Proses ini tidak dilakukan secara paksaan tetapi melalui norma-norma sosial komunikasi mengenai pendidikan dan perbualan bersama individu. Penggunaan proses sosialisasi yang bersesuaian/bertepatan seperti adil dan tidak keras menjadi sebab utama individu tidak mengulangi kesalahan lama. Sekiranya individu gagal memberi kerjasama dalam proses ini, mereka akan terus mengikuti segmen dialog di pusat pemulihan akhlak dan dikenakan pertimbangan moral 
atau penilaian akhlak. Proses kedua adalah individu di arah bertanggungjawab dengan kesalahan yang telah dilakukan. Ianya sebagai penebusan kesalahan (retribution) di atas kesalahan yang dilakukan.Antara intervensi penebusan kesalahan yang lazim dipraktiskan adalah dengan cara memberi perkhidmatan kepada komuniti (community services). Ketiga dan terakhir adalah individu dianggap berhutang dengan komuniti; dengan memberi jaminan di mana mereka tidak akan mengulangi kesalahan lama. Dalam memastikan proses ini berjalan lancar dan mencapai kejayaan, komuniti perlu terus kekal berkomunikasi/berhubung dan sentiasa membuka/peluang saluran integrasi di dalam masyarakat bagi membantu individu mengekalkan nilai-nilai kemasyarakatan yang dipupuk.

Family Group Conference (FGC) atau Persidangan Kumpulan Keluarga adalah salah satu program dalam sistem pengadilan restoratif yang digunakan untuk mengadili individu. FGC adalah sebuah program yang berasal daripada New Zealand yang mula dilaksanakan pada tahun 1989. Seterusnya, di awal abad 90-an FGC turut dilaksanakan di Australia di mana dikenali dengan nama Wagga Wagga yang terletak di bawah pengendalian pengawai polis dan pihak sekolah. Wagga Wagga ini berfungsi sebagai pembuka atau fasilitator kepada persidangan FGC (Bazemore \& Umbreit, 2001).Di antara matlamat persidangan FGC adalah untuk membuka peluang kepada pihak-pihak yang berkepentingan dan/atau mereka yang telah terjejas/tempias dengan kesalahan pesalah melibatkan diri secara terus dalam perbincangan dan pembuatan keputusan berhubung/mengenai hukuman yang bersesuian diletakkan kepada pesalah, berusaha mempertingkatkan kesedaran pesalah mengenai kesan-kesan akibat perbuatannya kepada orang sekeliling serta memberi peluang kepada pesalah untuk bertanggungjawab mengenainya dan melibatkan tanggungjawab kolektif sistem sokongan pesalah dalam memperbetulkan kesalahan pesalah serta membantu membentukkan semula tingkah laku pesalah di masa hadapan.

Satu lagi perkara penting yang perlu diberi perhatian oleh semua pihak stakeholders yang terlibat dalam inisiatif pemulihan untuk remaja perempuan yang terlibat dengan salahlaku seksual adalah kurikulum program restoratif perlu mengambilkira keperluan biologi mereka yang sedang hamil dan bakal menjadi ibu muda. Keperluan biologi ini tidak boleh sama sekali dipandang remeh. Ini kerana kajian lepas telah mendapati kebanyakan remaja atau kanakkanak perempuan yang hamil mempunyai tabiat kesihatan yang kurang baik atau rendah (poor) dan mereka tidak melakukan perubahan untuk gaya hidup kehamilan yang lebih sihat (Grady \& Bloom, 2004). Kebanyakan mereka memperolehi perkhidmatan rawatan kehamilan (prenatel care) yang sangat 
terhad dan/atau langsung tiada berbanding dengan perempuan dewasa yang hamil. Keadaan-keadaan ini menyebabkan remaja atau kanak-kanak yang hamil berisiko menghadapi keadaan kehamilan yang menyedihkan, kematian awal (gestational morbidity) dan berisiko kepada penyakit-penyakit seperti mempunyai berat badan berlebihan (excessive weigh gain), tekanan darah tinggi (preeclampsia), ketidakseimbangan pelvis (cephalopelvic disproportion), kesukaran kelahiran pramatang (premature labor dystocia), kelahiran bayi melalui pembedahan dan berlaku komplikasi semasa kelahiran bayi.

Selain perkhidmatan kesihatan, remaja hamil luar nikah juga amat memerlukan sokongan sosial (social support) untuk perkembangan diri serta bayi mereka. Kebanyakan mereka sering mendapat tekanan sosial negatif, pemulauan daripada orang sekeliling khususnya; rakan sebaya serta pengasingan daripada ibubapa mereka. Keadaan-keadaan ini mempunyai perkaitan atau hubungan dengan jumlah serta kualiti sokongan sosial yang diterima dan kesihatan mereka, kehidupan seharian mereka dan kesihatan dan kesejahteraan bayi mereka (Logsdon, Birkimer, Ratterman, Cahill \& Cahill, 2002; Clemmons, 2001).

Antara contoh model program untuk kesejahteraan kesihatan remaja hamil serta bayi mereka adalah Centering Pregnancyatau kehamilan berpusat. Program ini dilaksanakan oleh negara Amerika Syarikat semenjak tahun 1999 lagi. Model ini menekankan penilaian, pendidikan dan sokongan yang dianggap sebagai model yang berusaha memberi kesejahteraan kesihatan kepada mereka. Model ini adalah model rawatan perubatan untuk ibu hamil melalui pimpinan pemudah cara (facilitative leadership). Ia memberi fokus kepada penilaian pendidikan dan sokongan kumpulan (remaja hamil lain) secara terus ke arah kebertanggungjawab penjagaan diri sendiri. Badan pelaksana model terdiri daripada pelbagai kategori masyarakat seperti jururawat bidan, pekerja sosial, pakar pemakanan, jururawat berdaftar, penyelaras pendidikan, setiausaha dan pembantu perubatan. Anggotaanggota daripada kepelbagaian disiplin ini berjumpa setiap minggu untuk berbincang mengenai isu penjagaan klien untuk pembangunan kesejahteraan klien mereka.

Terdapat dua isu mengenai kebimbangan perkhidmatan kesihatan untuk remaja hamil; iaitu kebolehaksesan (accessibility) dan pemilikan (affordability). Mereka tidak boleh dinafikan hak serta akses mereka terhadap perkhidmatan kesihatan ibu dan bayi yang disediakan secara universal oleh kerajaan. Malah, perkhidmatan ini perlu melangkaui perkhidmatan sedia ada; iaitu harus merangkumi bimbingan dan nasihat mengenai penjagaan anak, 
penjagaan kesihatan diri ketika mengandung dan selepas melahirkan, serta khidmat nasihat kaunseling mengenai pemeliharaan anak dan/atau pemberian anak yang bakal dilahirkan kepada keluarga lain yang sanggup menjaga anak tersebut, serta khidmat perundingan mengenai kesan-akibat yang bakal dialami mereka sekiranya mereka mahu membesarkan anak yang dilahirkan sendiri, meneruskan persekolahan, atau akibat mental dan fizikal yang bakal dialami sekiranya bayi yang dilahirkan diserahkan kepada orang lain.

Selain itu, perkhidmatan kesihatan ibu dan bayi ini juga perlu merangkumi input-input positif berkaitan pendidikan seks (sex education). Pengkaji sedar yang pendidikan seks merupakan satu isu yang cukup sensitif di Malaysia; khususnya di dalam kalangan ibu bapa. Namun, samada suka atau tidak, masyarakat harus belajar menerima hakikat yang kedaifan kanak-kanak dan remaja mengenai seks merupakan antara punca utama penglibatan mereka dalam aktiviti seks yang seterusnya menyebabkan mereka hamil secara tidak sengaja. Kurikulum pendidikan seks yang sesuai dengan acuan nilai, norma dan kepercayaan agama masyarakat tempatan perlu diambil kira dalam pelaksanaan pendidikan ini. Pendidikan seks ini boleh menjadi faktor pelindung yang berpotensi besar untuk melindungi remaja perempuan ini daripada terlibat semula dengan aktiviti seks, setelah mereka keluar dari institusi ini.

\section{Modul program pembangunan kompetensi yang komprehensif sesuai dengan keperluan sosial semasa}

Program pemulihan restoratif amat menitikberat hak/kebajikan pesalah dengan memberi peluang kepada mereka untuk memperbetulkan semula keadaan serta membangunkan semula mereka menerusi penyerapan nilai-nilai dan kemahiran-kemahiran yang bersesuaian. Ini kerana kanak-kanak/remaja yang terlibat dengan aktiviti tingkah laku sosial/delikuensi bukanlah kerana mereka 'jahat' tetapi adalah disebabkan mereka kurang memahami mengenai perbuatan mereka (wrongfulness of their act) dan terpengaruh/terikut dengan model sosialisasi yang negatif (Walgrave, 2004). Siti Hajar dan Abd. Hadi (2009) juga setuju dengan pandangan ini. Mereka mendapati kanak-kanak/remaja yang tidak mempunyai kemahiran hidup lazimnya berisiko untuk terlibat dengan kejadian tingkah laku/delikuensi. Justeru, golongan ini amat memerlukan kemahiran hidup yang komprehensif.

Siti Hajar dan Abd. Hadi (2009) menyenaraikan komponen-komponen kemahiran hidup yang perlu disalurkan kepada remaja dan kanak-kanak berisiko.Komponen-komponen kemahiran hidup tersebut telah dipaparkan dalam Rajah A.Tiga kemahiran spesifik yang perlu disalurkan kepada remaja 
ini, yang perlu dimasukan ke dalam program kemahiran hidup sedia ada di TSP adalah kemahiran ilmu pengetahuan, kemahiran vokasional, dan kemahiran komunikasi.

Bercakap mengenai kemahiran ilmu pengetahun, pengkaji ingin bercakap mengenai pendidikan seks. Menurut Kohler, Manhart \& Lafferty (2008), program pendidikan seks adalah program yang seimbang dan realistik di mana mengalakkan remaja memperlambatkan melakukan hubungan seks sehingga mereka dewasa atau matang, mempromosikan amalan seksual yang selamat atau sihat, terbukti berkesan dalam memperlambatkan umur permulaan hubungan seks dan membantu meningkatkan penggunaan alatalat pencegahan kehamilan dalam kalangan remaja. Program pendidikan seks yang berkesan menggabungkan maklumat perubatan yang tepat mengenai pelbagai isu yang berkaitan dengan seksualiti; termasuklah keupayaan menahan diri, pencegahan kehamilan, melakukan hubungan seks dengan selamat dan kesedaran risiko melakukan hubungan seksual yang tidak terlindung atau selamat serta pembelajaran cara bagaimana untuk mengelakkan daripada melakukan hubungan seks. Pendidikan seks turut termasuk membangunkan kemahiran komunikasi, berundingan dan keengganan mengenai seksualiti.

Masih lagi berkisar kepada kemahiran ilmu pengetahuan, pengkaji berpendapat perlu ada satu sistem persekolahan khusus untuk remaja perempuan yang sedang hamil. Mereka boleh samada dibenarkan ke sekolahsekolah harian biasa, seperti kanak-kanak atau remaja lain; sepertimana yang diamalkan di negara maju seperti Amerika Syarikat, Britain dan Sweden. Ataupun, mereka boleh dibenarkan menghadari kelas pengajaran secara ekslusif yang dianjurkan oleh agensi-agensi yang dilantik oleh pihak institusi. Ataupun, pihak institusi mengadakan aktiviti pengajaran ilmu pengetahuan di dalam setting institusi itu sendiri; iaitu membawa masuk tenaga pengajar/guru ke dalam sekolah. 
Rajah A: Kemahiran hidup yang diperlukan oleh kanak-kanak/remaja berisiko

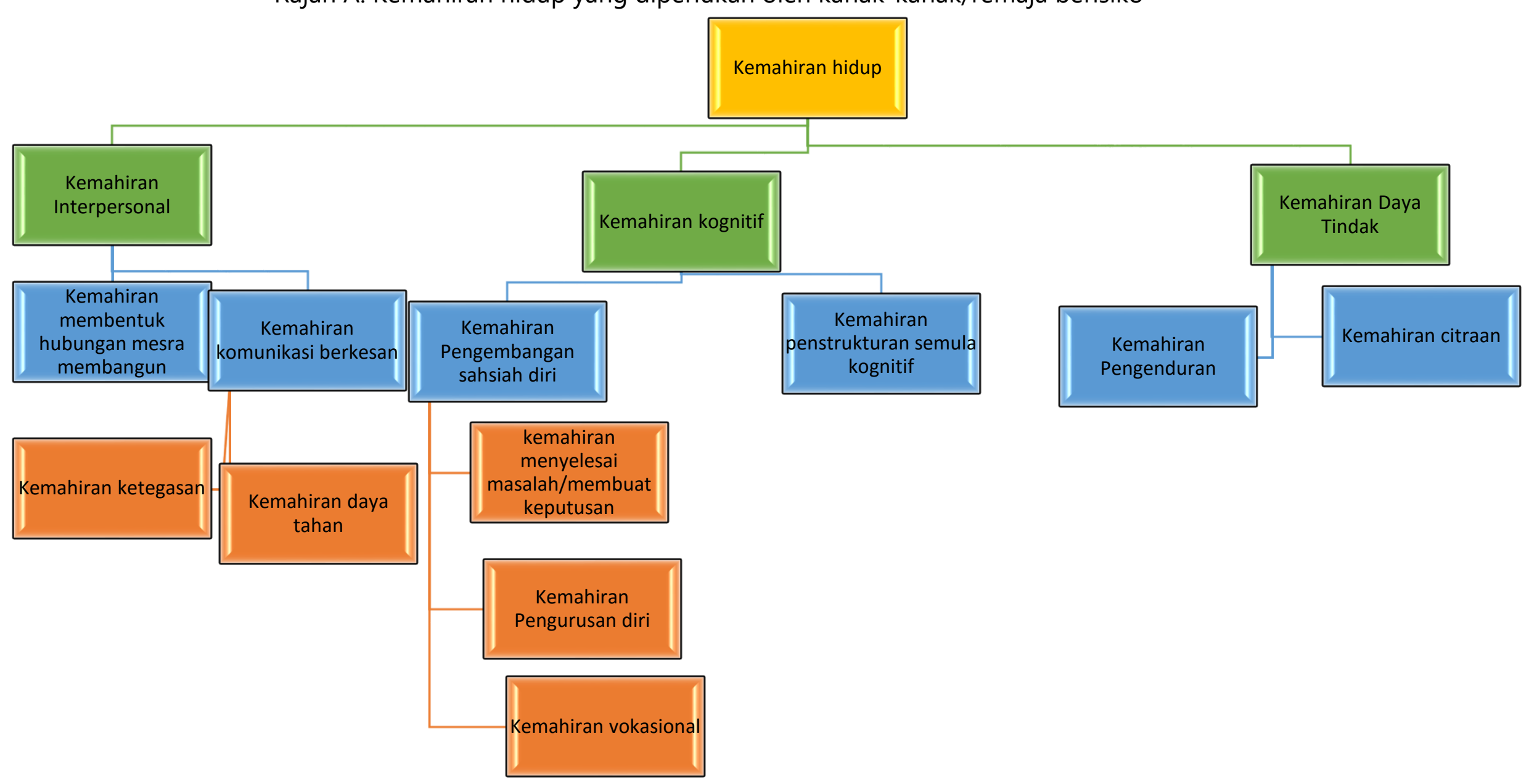


Teringat pengkaji kepada usaha kerajaan Negeri Melaka satu masa dulu membuka Sekolah Harapan di Jasin untuk remaja perempuan yang hamil. Ini merupakan satu usaha atau inisiatif sosial yang murni. Penubuhan sekolah tersebut adalah untuk memberi perlindungan atau sebagai tempat selamat kepada remaja hamil selain daripada menangani gejala buang bayi yang semakin berleluasa (Utusan Malaysia, 6 Disember, 2010). Pemilihan nama iaitu Sekolah Harapan adalah berdasarkan tujuan penubuhan sekolah tersebut diwujudkan di mana untuk memberi peluang kedua kepada remaja hamil luar nikah kembali ke pangkal jalan. Di awal penubuhannya, sekolah ini menyediakan empat buah kelas akademik yang mampu menampung antara 20 hingga 30 orang pelajar. Sekolah ini menyediakan sesi pembelajaran pelajar dari tingkatan dua hingga lima termasuk mereka yang bakal menduduki ujian Penilaian Menengah Rendah (PMR) dan Sijil Pelajaran Malaysia (SPM) (Utusan Malaysia, 21 Ogos, 2010). Sehingga Mac 2014, terdapat seramai 216 orang remaja hamil dari seluruh negara telah ditempatkan di sekolah berkenaan dengan mencatatkan 14 penghuni pada tahun 2010, 84 penghuni pada tahun 2011, 51 penghuni pada tahun 2012, 61 penghuni pada tahun 2013 dan 6 penghuni bagi bulan pertama tahun 2014 (Utusan Malaysia, 5 Mac, 2014).

\section{Modul "segmen dialog" dengan komuniti setempat (Rundingan Permuafakatan)}

Sistem pengadilan restoratif melibatkan komuniti sebagai pihak berkepentingan dalam pengadilan pesalah. Menurut Kurki (2000), di awal pelaksanaan sistem pengadilan restoratif di kebanyakan negara yang mengamalkannya, sistem ini hanya berfokuskan kepada usaha-usaha mewujudkan hubungan harmoni antara pesalah dan mangsa. Di Amerika Syarikat umpamanya, antara program restoratif terawal dilaksanakan adalah Victim Offender Reconciliation (VOR) atau Perdamaian Mangsa-Pesalah iaitu pada sekitar tahun 1970 dan 1980.

Menurut Lee (2009), antara peranan pihak komuniti dalam program pemulihan berasaskan pengadilan restoratif adalah berkongsi kesan/kemudaratan akibat perbuatan pesalah, mengadakan perbincangan mengenai langkah-langkah yang perlu diambil dalam menangani masalah pesalah serta mengadakan perbincangan bersama pesalah mengenai langkahlangkah yang perlu diambil oleh pesalah di atas kesalahan yang telah mereka lakukan. Peranan-peranan di atas adalah bertujuan untuk menangani/mengendalikan masalah-masalah yang berlaku dan sebagai pemulihan/pembaikan (reparative) pesalah yang seterusnya menggalakkan pemasukan semula mereka ke dalam komuniti (reintegration). 
Hasil penilaian terhadap keberkesanan program pemulihan berasaskan pengadilan restoratif oleh kajian-kajian lepas mendapati terdapat bukti kukuh di mana proses integrasi dan membaik pulih kemudaratan/kerosakan yang dikenakan ke atas pesalah sukar dicapai tanpa bantuan komuniti (Gerkin, 2012). Ini kerana sistem pengadilan restoratif memberi peluang kepada komuniti untuk terlibat dalam penyelesaian konflik, memberi sokongan kepada pesalah, mengingtegrasi semula pesalah dan memperkukuhkan lagi nilai-nilai kemasyarakatan kepada pesalah. Melalui penglibatan dalam program restoratif, komuniti mempunyai potensi menjadi peserta yang aktif dalam membantu mengurangkan kesalahan melalui kekuatan social cohesion, kepercayaan, penyerapan nilai-nilai masyarakat dan mengintegrasikan semula pesalah ke dalam ahli-ahli komuniti (Dhami \& Joy, 2007; Rodriguez, 2005; Zehr \& Mika, 1998).

Malangnya, analisis daripada data-data kajian menunjukkan institusi pemulihan TSP sama sekali tidak menitikberatkan penglibatan komuniti setempat dalam membantu membaikpulih penghuninya. Penglibatan komuniti perlu dilaksanakan di institusi ini memandangkan rata-rata responden kajian merasakan adalah penting untuk mereka diberi peluang bersua muka dan/atau berunding bersama komuniti setempat. Justifikasi mereka adalah:

1. Perundingan bersama anggota komuniti setempat mampu membantu mereka menyelesaikan masalah yang mereka alami,

2. Komuniti setempat mampu membantu mereka menyelesaikan masalah semasa dalam pusat pemulihan,

3. Perundingan dengan komuniti setempat; khususnya dengan pihak keluarga mampu membantu mereka membaiki hubungan dengan ahli keluarga,

4. Perundingan ini memberi mereka ruang untuk bersuara walaupun hanya dengan kakitangan institusi pemulihan,

5. Perundingan bersama anggota komuniti setempat merupakan satu medium untuk mereka duduk bersama-sama berbincang menyelesaikan masalah bagi mengelakkan pihak institusi menghukum mereka secara tergesa-gesa,

6. Perundingan bersama anggota komuniti ini mampu membantu mereka merasakan kepentingan untuk merapatkan hubungan dengan orang sekeliling dan menerima bantuan dan/atau tunjuk ajar dalam pembuatan keputusan yang bijak; dan, 
7. Perundingan bersama anggota komuniti ini menyediakan satu ruang sosial kepada pergaulan yang lebih luas, tidak hanya duduk terperap dalam institusi pemulihan sahaja.

Wenzel, Okimoti, Feather dan Platow (2008) mengatakan sistem pengadilan restoratif melihat sesuatu kesalahan yang berlaku telah menimbulkan konflik. Di antaranya konflik pesalah dengan komuniti serta pihak-pihak berkepentingan yang lain dan seterusnya konflik-konflik tersebut perlu diselesaikan melalui proses interaksi dalam kalangan mereka. Melalui amalan ini, mereka telah diberi peluang bersuara untuk meluahkan perasaan dan pandangan mereka mengenai kesalahan. Perlaksanaannya melibatkan pengumpulan sebahagian daripada mereka yang telah terjejas dengan kesalahan pesalah bersemuka untuk berbincang dan menyelesaikan kesalahan tersebut. Perbincangan diadakan di tempat yang telah diatur/ditetap dan di yakini selamat. Kebiasaanya perbincangan turut melibatkan keluarga, rakan sebaya, penyokong pesalah atau mana-mana ahli dalam komuniti yang berkepentingan dalam perbincangan tersebut. Elemen yang dibawa oleh prosedur ini adalah 'untuk membawa kesemua pihak-pihak berkepentingan berdialog mengenai kesan/akibat kesalahan pesalah. Lee (2009) mengatakan keberkesanan amalan dalam sistem pengadilan restoratif adalah bergantung kepada penglibatan kepelbagaian pihak berkepentingan yang telah terjejas/terlibat dengan kesalahan yang berlaku.

Intipati proses dialog ini adalah menjurus ke arah membuatkan pesalah bertanggungjawab di atas kemudaratan/kerosakan yang disebabkan mereka, berusaha mengubah/memperbaikinya, menunjukkan penyesalan dan menawarkan permohonan maaf (Wenzel et al., 2008). Menurut Dzur (2003b) segmen dialog ini tidak melibatkan institusi pengadilan atau pemulihan rasmi atau formal di mana ianya tidak didominasi oleh mana-mana profesional dan prosedur-prosedur yang telah ditetapkan sebagaimana dalam sistem pengadilan rasmi. Segmen dialog ini adalah hanya di antara komuniti dan pihak-pihak yang berkepentingan bersama pesalah. Tambah beliau lagi terdapat tiga perkara yang hendak dicapai semasa segmen dialog tersebut iaitu membaiki kemudaratan/kerosakan (repairing harm), pengampunan atau kemaafan (achieving forgiveness) serta pemasukan semula pesalah ke dalam komuniti (reintregration offender).

Terdapat beberapa tanggungjawab atau peranan yang perlu dimainkan oleh komuniti dalam sistem pengadilan restoratif. Ianya seperti komuniti menunjukkan kesungguhan ataupun sedaya upaya memastikan pesalah bertanggungjawab dengan kesalahannya, memulihkan pesalah dan berusaha 
dalam memastikan ketenteman/keselamatan komunitinya, turut bekerja dengan pesalah dalam projek khidmat masyarakat, menyokong pihak-pihak berkepentingan lain, menyediakan sokongan untuk pesalah iaitu sebagai mentor, majikan dan/atau penyokong buat mereka, menyediakan peluang kepada pesalah untuk memperbaiki kemudaratan/kerosakan serta peluang mempelajari kemahiran-kemahiran berguna dan juga membenarkan pesalah membuat sumbangan yang bermakna kepada komuniti, komuniti turut digalakkan membantu keluarga pesalah untuk menyokong pesalah melaksanakan tanggungjawab yang ditetapkan kepada mereka sebaik mungkin dan tanggungjawab meningkatkan kompetensi diri mereka dan komuniti berfungsi sebagai penasihat kepada mahkamah serta berperanan aktif dalam hal-hal melibatkan kejiranan mereka (Bazemore, 1998).

Zehr dan Mika (1998) pula mengatakan proses pengadilan restoratif komuniti ini dijalankan dengan beberapa cara seperti ahli-ahli dalam komuniti bergiat aktif dalam menjalankan pengadilan, proses pengadilan mengemukan sumber-sumber daripada komuniti dan seterusnya menyumbang kepada kekuatan dan pembangunan komuniti dan proses keadilan berusaha untuk mengalakkan perubahan dalam komuniti dan pesalah dan seterusnya mencegah kesalahan yang sama berlaku kepada mereka yang lain dan untuk mengalakkan pencegahan awal dengan mengenalpasti keperluan pihak terjejas/tempias dan tanggungjawab pesalah.

\section{Kesimpulan}

Kajian ini mendapati ciri-ciri program pemulihan yang berasaskan pendekatan pengadilan restoratif tidak dilaksanakan secara terperinci di TSP. Malah, perkataan "restoratif" itu sendiri merupakan satu tema yang "aneh" untuk remaja perempuan yang mengikuti perkhidmatan pemulihan dan perlindungan di institusi ini. Aktiviti penanaman sikap bertanggungjawab dalam diri kanak-kanak juga begitu cetek; iaitu lebih terfokus kepada tanggungjawab untuk menjaga bayi yang bakal dilahirkan. Sikap bertanggungjawab terhadap diri sendiri, keluarga dan komuniti tidak disentuh secara mendalam. Begitu juga dengan ciri pembangunan kompetensi diri. Aktiviti pembangunan kompetensi diri masih lagi terfokus kepada aktivitiaktiviti konvensional seperti sains rumah tangga, memasak, menjahit, membuat roti, berkebun dan sebagainya. Manakala program rundingan permuafakatan komuniti pula tiada langsung dilaksanakan. Sekiranya penghuni ingin meluahkan perasaan atau masalah, mereka digalakkan untuk berjumpa/berbincang mengenainya dengan kaunselor yang ditempatkan di 
institusi pemulihan dan/atau cuba menyelesaikan sendiri. Pendek kata, program pemulihan teraputik yang berasaskan pendekatan pengadilan restoratif tidak diambil serius di dalam program pemulihan sosial di TSP. Bersesuaian dengan dapatan-dapatan tersebut, pengkaji telah mencadangkan beberapa tindakan intervensi yang boleh diambil bagi menerapkan amalan restoratif ke dalam perkhidmatan perlindungan dan pemulihan awam kanakkanak di Malaysia.

\section{Rujukan}

Allan, A., Beesley, S.M., Attwood, B., \& Mckillop, D. (2013). Apology in Restorative and Juvenile Justice. Psychiatry, Psychology and Law, 21(2), 176190.

Akta Kanak-Kanak 2001 (Akta 611). (2011). Kuala Lumpur: International Law Book Services.

Akta Kanak-Kanak (pindaan) 2016 (Akta 1511). Diakses Pada 1 Mac 2017, Dari http://www.federalgazette.agc.gov.my/outputaktap/20160725_A1511_BM_WJ W006870\%20BM.pdf

Barton, W. H. (2000). Alternative in Juvenile Corrections. Indiana Family Impact Seminars, 38-59. Diakses Pada 10 November 2013, Dari http://www.familyimpactseminar.org/sinfis02c03.pdf

Bazemore, G. (1997). The 'Community' in Community Justice: Issues, Themes and Questions for the New Neighborhood Sanctioning Models. The Justice System Journal, 19 (2), 193-228.

Bazemore, G. (1998). Restorative Justice and Earned Redemption: Communities, Victims and Offender Reintegration. The American Behavioral Scientist, 41(6), 768-813.

Bazemore, G., \& Day, S. E. (1996). Restorative the Balance: Juvenile and Community Justice. A Journal of the Office of Juvenile Justice and Delinquency Prevention, 3(1), 3-14.

Bazemore, G., \& Umbreit, M. (2001). A Comparison of Four Restorative Conferencing Models. U.S. Department of Justice: Office of Juvenile Justice and Delinquency Prevention, 1-20. Diakses Pada 1 Disember 2016, Dari https://www.ncjrs.gov/pdffiles1/ojjdp/184738.pdf 
Bazemore, G., \& Umbreit, M. (2004). Balanced And Restorative Justice. United State: Office Of Justice Programs \& Office Of Juvenile Justice and Delinquency Prevention, Department Of Justice.

Braithwaite, J. (2000). Restorative Justice and Social Justice. Saskatchewan Law Review, 63(1), 185-194.

Braithwaite, J. (2002a). Restorative Justice and Responsive Regulation. Oxford: Oxford University Press. Dalam Walgrave, L. (2004). Restorative in Youth Justice. Chicago Journal, 31, 543-597.

Braithwaite, J. (2002b). Restorative Justice and Therapeutic Jurisprudence. Criminal Law Bulletin, 38(2), 244-262.

Challeen, D. A. (1986). Making It Right: A Common Sense Approach to Criminal Justice. Saint George: Melius \& Peterson.

Choi, J. J., \& Severson, M. (2009). "What! What Kind Of Apology Is This?": The Nature Of Apology In Victim Offender Mediation. Children and Youth Services Review, 31, 813-820.

Clemmons, D. (2001). The Relationship between Social Support and Adolescent Mothers' Interactions with Their Infants: A Meta-Analysis. Journal of Obstetric, Gynecologic \& Neonatal Nursing, 30(4), 410-420.

Daly, K. (2005). Restorative Justice and Sexual Assault: An Archival Study of Court and Conference Cases. British Journal of Criminology, 1-30.

Dhami, M. \& Joy, P. (2007). Challenges to establishing, volunteer-run, community-based restorative justice programs. Contemporary Justice Review, 10 (1), 9-22.

Dzur, A. W. (2003a). Restorative Justice and Civic Accountability for Punishment. North Eastern Political Science Association, 36 (1), 3-22.

Dzur, A. W. (2003b). Civic Implications of Restorative Justice Theory: Citizen Participant and Criminal Justice Policy. Policy Sciences, 36 (3/4), 279-306.

Elis, L. (2005). Restorative Justice Program, Gender and Recidivism. Public Organization Review, 5, 375-389. 
Ellis, R. A., \& Sowers, K. M. (2001). Juvenile Justice Practice: A Cross-Disciplinary Approach To Intervention. USA: Thomson Learning.

Exline, J. J., Worthington, E. L., Hill, P., \& Mccullough, M. E. (2003). Forgiveness and Justice: A Research Agenda for Social and Personality Psychology. Personality and Social Psychology Review, 7, 337-348.

Gerkin, P. M. (2012). Who owns this conflict? The challenge of community involvement in restorative justice. Contemporary Justice Review: Issues in Criminal, Social and Restorative Justice, 15 (3), 277-296.

Grady, M. A., \& Bloom, K. C. (2004). Pregnancy Outcomes Of Adolescents Enrolled in A Centering Pregnancy Program. American College Of NurseMidwive, $49(5), 412-420$.

Henggeler, S. W., \& Scheonwald, S. K. (2011). Social Policy Report: EvidenceBased Interventions for Juvenile Offenders and Juvenile Justice Policies that Support Them. Society for Research in Child Development, 25(1), 1-28.

Kohler, P. K., Manhart, L. E., \& Lafferty, W. E. (2008). "Abstinence-Only and Comprehensive Sex Education and the Initiation of Sexual Activity and Teen Pregnancy". Journal of Adolescent Health, 42 (2), 344-351.

Kurki, L. (2000). Restorative and Community Justice in the United States. Chicago Journals, 27, 235-303.

Latimer, J., Dowden, C., \& Muise, D. (2005). The Effectiveness of Restorative Justice Practices: A Meta-Analysis. The Prison Journal, 85(2), 127-144.

Latimer, J., \& Kleinknecht, S. (2000). The Effects of Restorative Justice Programming: A Review of the Empirical Research Literature. Ottawa: Research and Statistics Division, Department Of Justice Canada.

Law Commission. (2000). From Restorative Justice to Transformative Justice. Ottawa: Law Commission of Canada.

Lawson, C. L., \& Katz, J. (2004). Restorative Justice: An Alternative Approach to Juvenile Crime. Journal of Socio-Economics, 33, 175-188. 
Lee, F. (2009). Adopting Restorative Approach to Young Offenders in Hong Kong: A Pulic Survey. Contemporary Justice Review: Issues in Criminal, Social, and Restorative Justice, 12(4), 469-483.

Lipsey, M. W. (2009). The Primary Factors that Characterize Effective Interventions with Juvenile Offenders: A Meta-Analytic Overview. Victims and Offenders, 4, 124-147.

Lipsey, M. W., Howell, J. C., Kelly, M. R., Chapman, G., \& Carver, D. (2010). Improving the Effectiveness of Juvenile Justice Programs. A New Perspective on Evidence-Based Practice. Washington, DC: The Center for Juvenile Justice Reform.

Llewllyn, J. T., \& Howse, R. (1999). Institutions for Restorative Justice: The South African Truth and Reconciliation Commission. The University of Toronto Law Journal, 49, 355-388.

Logsdon, M. C., Birkimer, J. C., Ratterman, A., Cahill, K., \& Cahill, N. (2002). Social Support in Pregnant and Parenting Adolescent: Research, Critique and Recommendations. Journal of Child and Adolescent Psychiatric Nursing, 15(2), 75-83.

Maloney, D., Romig, D., \& Armstrong, T. (1998). The Balances Approach to Juvenile Probation. Juvenile \& Family Court Journal, 39, 1-4.

Melton, A. (1995). Indigenous Justice System and Tribal Society. Judicature, 70 (3), 126-133.

Mohd Al Adib Samuri \& Noor Aziah Mohd Awal (2009). Hukuman terhadap pesalah kanak-kanak di Malaysia: pencegahan atau pemulihan?. Jurnal Undang-Undang, 13, 35-54.

Rodriguez, N. (2005). Restorative Justice, Communities and Delinquency: Whom Do We Reintegrate Criminology \& Public Policy, 4(1), 103-130.

Siti Hajar Abu Bakar., \& Abd. Hadi Zakaria. (2009). Perlindungan Kanak-Kanak Berisiko. Kuala Lumpur: Penerbit Universiti Malaya.

Smith, M. (2001). What Future For "Public Safety" And "Restorative Justice" In Community Corrections?. Washington, DC: U.S. Department of Justice, National Institute of Justice. 
Spence, S. H. (2003). Social Skills Training With Children and Young People: Theory, Evidence and Practice. Child and Adolescent Mental Health, 8 (2), 8496.

Stuart, B. (1996). Circle Sentecing: Turning Swords into ploughshares. Dalam B. Galaway \& J. Hudson (Eds.), Restorative Justice International Perspectives (pp. 193-206). Monsey, NY: Criminal Justice Press.

Umbreit, M. S. (1994). Crime Victims Confront Their Offenders: The Impact Of A Minneapolis Mediation Program. Research on Social Work Practice, 4, 436447.

U. S. Department of Education. (2013). Supporting the Academic Success of Pregnant and Parenting Students. Diakses pada 3 Mac 2014, dari http://www2.ed.gov/about/offices/list/ocr/docs/pregnancy.pdf

Utusan Malaysia. (2010). 21 Ogos. Sekolah Harapan Untuk Pelajar Hamil.

Utusan Malaysia. (2010). 6 Disember. Sekolah Harapan Ditutup Jika Tiada Lagi Kes.

Utusan Malaysia. (2014). 5 Mac. 201 Kelahiran Bayi Direkod Di Sekolah Harapan.

Walgrave, L. (2004). Restorative in Youth Justice. Chicago Journal, 31, 543-597.

Wenzel, M., Okimoto, T. G., Feather, N. T., \& Platow, M. J. (2008). Retributive and Restorative Justice. Law and Human Behaviour. 32(5), 375-389.

Zehr, H. (1990). Changing Lenses: A New Focus for Crime and Justice. Scottdale, PA: Herald Press.

Zehr, H., \& Mika, H. (1998). Fundamental concepts of restorative justice. Contemporary Justice Review, 1, 47-55. 